\title{
Chromomycin A3 suppresses cholangiocarcinoma growth by induction of $S$ phase cell cycle arrest and suppression of Sp1-related anti-apoptotic proteins
}

\author{
PAKSIREE SARANARUK ${ }^{1,2}$, RYUSHO KARIYA ${ }^{3}$, GUNYA SITTITHUMCHAREE ${ }^{3}$, PARICHART BOUEROY ${ }^{4}$, \\ THIDARUT BOONMARS ${ }^{2,5}$, KANLAYANEE SAWANYAWISUTH ${ }^{1,2}$, CHAISIRI WONGKHAM $^{1,2}$, \\ SOPIT WONGKHAM ${ }^{1,2}$, SEIJI OKADA ${ }^{3}$ and KULTHIDA VAETEEWOOTTACHARN ${ }^{1-3}$

\begin{abstract}
${ }^{1}$ Department of Biochemistry, Faculty of Medicine, and ${ }^{2}$ Cholangiocarcinoma Research Institute, Khon Kaen University, Khon Kaen 40002, Thailand; ${ }^{3}$ Division of Hematopoiesis, Joint Research Center for Human Retrovirus Infection and Graduate School of Medical Sciences, Kumamoto University, Kumamoto 860-0811, Japan; ${ }^{4}$ Faculty of Public Health, Kasetsart University Chalermphrakiat Sakon Nakhon Province Campus, Sakon Nakhon 47000; ${ }^{5}$ Department of Parasitology, Faculty of Medicine, Khon Kaen University, Khon Kaen 40002, Thailand
\end{abstract}

Received July 24, 2019; Accepted December 10, 2019

DOI: $10.3892 /$ ijmm.2020.4482

\begin{abstract}
Cholangiocarcinoma (CCA) is a cancer of biliary epithelium. Late diagnosis and resistance to conventional chemotherapy are the major obstacles in CCA treatment. Increased expression of anti-apoptotic proteins are observed in CCA, which might confer chemoresistance. Thus, modulations of anti-apoptotic proteins leading to apoptotic induction is the focus of this study. Chromomycin A3 (CMA3), an anthraquinone glycoside-mithramycin $\mathrm{A}$ analog, was selected. CMA3 strongly binds to GC-rich regions in DNA, where specificity protein 1 ( $\mathrm{Sp} 1)$, a common transcription factor of apoptosis-related proteins, is preferentially bounded. The effects of CMA3 on anti-proliferation, cell cycle arrest and apoptosis induction in CCA cells were demonstrated by MTT assay, flow cytometry and western blot analysis. The results showed CMA3 suppressed cell proliferation in vitro in the $\mathrm{nM}$ range. At low doses, CMA3 inhibited cell cycle progression at $\mathrm{S}$ phase, while it promoted caspase-dependent apoptosis at higher doses. CMA3 induced effects of apoptosis were through the suppression of Sp1-related anti-apoptotic proteins, FADD-like IL-1 $\beta$-converting enzyme-inhibitory
\end{abstract}

Correspondence to: Dr Kulthida Vaeteewoottacharn, Department of Biochemistry, Faculty of Medicine, Khon Kaen University, 123 Mittapap Road, Muang, Khon Kaen 40002, Thailand

E-mail: kulthidava@kku.ac.th

Professor Seiji Okada, Division of Hematopoiesis, Joint Research Center for Human Retrovirus Infection and Graduate School of Medical Sciences, Kumamoto University, 2-2-1 Honjo, Chuo-ku, Kumamoto 860-0811, Japan

E-mail: okadas@kumamoto-u.ac.jp

Key words: cholangiocarcinoma, chromomycin A3, Sp1, anti-apoptotic proteins, apoptosis, cell cycle arrest, $\mathrm{S}$ phase protein, myeloid cell leukemia-1, X-linked inhibitor of apoptosis protein, cellular inhibitor of apoptosis and survivin. The anti-CCA effects of CMA3 were confirmed in the xenograft mouse model. CMA3 retarded xenograft tumor growth. Taken together, CMA3 induced apoptosis in CCA cells by diminishing the Sp1-related anti-apoptotic proteins is demonstrated. CMA3 might be useful as a chemosensitizing agent.

\section{Introduction}

Cholangiocarcinoma (CCA) is a malignancy of biliary epithelium, which is the second most common primary liver cancer worldwide. The global incidence of CCA is $<6 / 100,000$ people but it is $85 / 100,000$ people in Northeastern Thailand (1), where the high prevalence of the carcinogenic liver fluke, Opisthorchis viverrini, infection is reported (2). Nonetheless, mortality rates of intrahepatic CCA have also increased in other continents (3). CCA is a devastating cancer in that patients are often diagnosed at a late stage when complete resection is not a curative option (4). CCA is well known for the low response to currently available chemotherapy (5). The effectiveness of available pharmacological treatments is limited by several mechanisms of chemoresistance $(5,6)$.

The resistance to chemotherapy is a major challenge in CCA treatment. The common mechanisms of CCA chemoresistance are i) reduced intracellular drug concentration, ii) altered drug metabolism, iii) changed drug targets, iv) enhanced DNA repair, v) changes in cancer microenvironment and vi) altered balance between survival and apoptotic signals (5). The present authors have previously reported increased expression of the specific adenosine triphosphate binding cassette (ABC) transporter superfamily member; $\mathrm{ABCC} 1$, in $\mathrm{CCA}$ and its contribution to worse prognosis (7), but the clinical benefits of an ABCC1 inhibitor are yet to be proven. The disturbance of pro- and anti-apoptotic signals and the potential in CCA treatment were focused on in the current study. 
The increased anti-apoptotic proteins, such as B-cell lymphoma 2 (Bcl-2), B-cell lymphoma-extra-large (Bcl-xL), cellular inhibitor of apoptosis (cIAP) (8), FADD-like IL-1 $\beta$-converting enzyme-inhibitory protein (FLIP) (9), myeloid cell leukemia-1 (Mcl-1), X-linked inhibitor of apoptosis protein (XIAP) $(10,11)$ and survivin (12) in CCA cells have been previously reported and these contribute to apoptotic evasion. On the contrary, suppression of selected anti-apoptotic proteins induce apoptosis and suppress CCA growth in vivo $(8-10,12)$. The increased expression of multiple anti-apoptotic proteins usually occurred simultaneously. Therefore, this study aimed to find an FDA-approved agent that could downregulate anti-apoptotic proteins.

A number of anti-apoptotic genes (e.g. Mcl-1, survivin and XIAP) are under the regulation of specificity protein 1 (Sp1) transcription factor (13). Sp1 binds to GC-rich sequences on their promoters and promotes transcription (13). Even though $\mathrm{Spl}$ is highly controlled during development, over-expression of $\mathrm{Sp} 1$ is often reported in cancers and contributes to poor prognosis $(14,15)$. Thus, suppression of $\mathrm{Sp1}$ or interference of Sp1 binding to a target promoter is considered a novel strategy for cancer treatment $(13,16)$. According to current understanding, among FDA-approved anti-cancer agents, mithramycin A (MTA) is a selective Sp1 inhibitor, which suppresses Sp1-related anti-apoptotic gene expression and induces caspase-dependent apoptosis $(17,18)$. There are reports, however, that chromomycin A3 (CMA3), an MTA analog, possesses higher DNA binding capacity and has demonstrated similar effects on neurons $(19,20)$. Therefore, CMA3 might exhibit potent Sp1-related gene suppression. CMA3 was selected for the current studies.

CMA3 is an anthraquinone glycosidic antibiotic, produced by Streptomyces griseus (21). The anti-cancer effects of CMA3 have been proposed since the 1960s $(22,23)$. Side effects of CMA3 in advanced breast cancers have interrupted that use (24) but it is widely used for DNA staining (25). DNA binding ability of CMA3 has been elucidated; CMA3 binds to a GC-rich sequence at a minor groove and inhibits DNA replication and transcription (26). It has been reported that CMA3 induced cervical cancer cell apoptosis but the underlying mechanism is still obscure (27). Therefore, the anti-CCA potentials of CMA3 and its effects on Sp1-related anti-apoptotic proteins were focused on.

\section{Materials and methods}

Cell lines and cell culture. A total of three CCA cell lines, KKU-055, KKU-100 and KKU-213, were established as previously described (28). Cells were obtained from the Japanese Collection of Research Bioresources Cell Bank. Cells were maintained in Dulbecco's modified Eagle's medium (Wako Pure Chemical Industries, Ltd.) containing 10\% fetal bovine serum (HyClone; GE Healthcare), $100 \mathrm{U} / \mathrm{ml}$ penicillin and $100 \mu \mathrm{g} / \mathrm{ml}$ streptomycin. CCA cells were cultured in a humidified incubator at $37^{\circ} \mathrm{C}$ with $5 \% \mathrm{CO}_{2}$.

Reagents and antibodies. CMA3 was purchased from Abcam, MTA was from Sigma-Aldrich; Merck KGaA, MTT and propidium iodide (PI) were from Sigma-Aldrich; Merck KGaA, RNase A was from Takara Bio, Inc., and Pacific Blue $^{\mathrm{TM}}$ Annexin V was from BioLegend, Inc.
Sources of antibodies were as follows: Rat anti-Hsc70 (1B5 clone; cat. no. ADI-SPA-815B) monoclonal antibody (mAb) was from EnZo Life Sciences, Inc.; rabbit anti-Bim (C34C5 clone; cat. no. 2933) $\mathrm{mAb}$, rabbit anti-cleaved caspase-3 (Asp175; 5A1E clone; cat. no. 9664) mAb, rabbit anti-cleaved caspase-8 (Asp391; 18C8 clone; cat. no. 9496) mAb and rabbit anti-cleaved caspase-9 (Asp315; D8I9E clone; cat. no. 20750) $\mathrm{mAb}$, horseradish peroxidase (HRP)-linked anti-rabbit IgG (cat. no. 7071), and HRP-linked anti-mouse IgG (cat. no. 7076) were from Cell Signaling Technology, Inc.; mouse anti-FLIP short and long forms $\left(\right.$ FLIP $_{S / L}$; G-11 clone; cat. no. sc-5276) $\mathrm{mAb}$, mouse anti-Mcl-1 (22 clone; cat. no. sc-12756) mAb, mouse anti-Noxa (114C307 clone; cat. no. sc-56169) mAb, mouse anti-survivin (D8 clone; cat. no. sc-17779) mAb, rabbit anti-cIAP2 (H-85 clone; cat. no. sc-7944) polyclonal antibody (pAb), rabbit anti-Sp1 (PEP 2 clone; cat. no. sc-59) pAb, and rabbit anti-XIAP (H-202 clone; cat. no. sc-11426) pAb, were from Santa Cruz Biotechnology, Inc.; mouse anti-BAX (2D2 clone; cat. no. 633601) mAb was from Biolegend, Inc.; mouse anti- $\alpha$-smooth muscle actin ( $\alpha$-SMA; 1 A 4 clone; cat. no. M0851) mAb, and rabbit anti-rat (cat. no. P0450) pAb were from Dako; Agilent Technologies, Inc.; mouse anti-cytokeratin (AE1\&AE3 clone; cat. no. 313M) cocktail was from Cell Marque $^{\mathrm{TM}}$ (Sigma-Aldrich; Merck KGaA); rabbit anti- cytokeratin 19 (CK19; cat. no. HPA002465) was from Sigma-Aldrich (Merck KGaA); rabbit anti-BAX (E63 clone; cat. no. ab32503) pAb, and rabbit anti-caspase-9 (cat. no. ab2014) pAb were from Abcam and the rabbit anti-Ki-67 (30-9 clone; cat. no. 790-4286) $\mathrm{mAb}$ was from Ventana Medical Systems, Inc.

Tetrazolium dye MTT assay. The anti-proliferative effects of CMA3 on KKU-055, KKU-100 and KKU-213 CCA cells were determined by MTT assay. CCA cells were seeded at $4 \times 10^{3}$ cells per well into a 96-well plate. At $24 \mathrm{~h}$ after seeding, CMA3 or MTA were added at different concentrations $(0,2.5$, $5,10,20,40,80$ and $160 \mathrm{nM}$ for CMA3 and $0,12.5,25,50$, 100 and $200 \mathrm{nM}$ for MTA) and cells were incubated for 24 and $48 \mathrm{~h}$. MTT solution was added to obtain a final concentration of $0.5 \mathrm{mg} / \mathrm{ml}$. Then formazan crystals were dissolved by acidified isopropanol $(0.04 \mathrm{~N} \mathrm{HCl}$ in isopropanol). The absorbance was measured at $570 \mathrm{~nm}$ using a microplate reader (iMark; Bio-Rad Laboratories, Inc.). The data were analyzed using the GraphPad Prism 8 (GraphPad Software, Inc.). The optical density $_{570}$ of the control was set to $100 \%$.

Cell cycle analysis. Cells were treated at indicated concentrations of CMA3 for $24 \mathrm{~h}$. After that cells were harvested and fixed with cold $70 \%$ ethanol overnight at $4^{\circ} \mathrm{C}$. Before analysis, cells were washed with PBS and incubated with $0.1 \mathrm{mg} / \mathrm{ml}$ of RNase A at $37^{\circ} \mathrm{C}$ for $1 \mathrm{~h}$, followed by PI staining $(50 \mu \mathrm{g} / \mathrm{ml})$ at $4^{\circ} \mathrm{C}$ for $30 \mathrm{~min}$ in the dark. Samples were analyzed by LSR II flow cytometer (BD Biosciences; Becton, Dickinson and Company) and data were analyzed by FlowJo software version 10.4 (Tree Star, Inc.).

Annexin $V$ binding assay. Cells were treated with various concentrations of CMA3 for $24 \mathrm{~h}$. Then cells were collected and incubated with Pacific Blue ${ }^{\mathrm{TM}}$ Annexin V at room temperature for $30 \mathrm{~min}$ in the dark. PI was added at the final concentration of $1 \mu \mathrm{g} / \mathrm{ml}$ before flow cytometry analysis. 
Annexin V and PI-stained cells were determined by flow cytometry. Annexin V-bound and PI-stained cells were analyzed by FlowJo software.

Western blot analysis. KKU-213 cells were treated with CMA3 at indicated concentrations and times. Protein lysate was prepared as described elsewhere (29). Protein concentrations were determined by the bicinchoninic acid protein assay (Thermo Fisher Scientific, Inc.). A total of $20 \mu \mathrm{g}$ of protein was separated by SDS-PAGE (10-15\%) and transferred to a PVDF membrane (GE Healthcare Japan). The membrane was blocked with $5 \%$ skim milk in Tris-buffered saline containing $0.1 \%$ Tween-20 (TBST) at room temperature for $30 \mathrm{~min}$ and was incubated with specific primary antibodies $(1: 1,000)$ at $4^{\circ} \mathrm{C}$ overnight. Membranes were washed with TBST 3 times prior to the incubation with the corresponding HRP-conjugated secondary antibody $(1: 2,000)$ for $1 \mathrm{~h}$ at room temperature. Signals were detected using Chemi-Lumi One Super reagents (Nacalai Tesque, Inc.) and visualized by ImageQuant LAS 4000 system (GE Healthcare Japan). The quantitative analyses of blots were quantified by Image J (30). Hsc70 was used as an internal control.

Reverse-transcriptase-polymerase chain reaction (RT-PCR). KKU-213 cells were treated with $40 \mathrm{nM}$ CMA3 or $200 \mathrm{nM}$ MTA for 0, 6, 12, 18 and $24 \mathrm{~h}$. RNA preparation and RT-PCR were performed as previously described (31). Gene expression was presented as relative expression (fold, control at $0 \mathrm{~h}=1$ ). The oligonucleotide primers used in this study were previously reported elsewhere; $M c l-1$ (32), XIAP (33), $\beta$-actin (34).

CMA3 toxicity testing. To demonstrate the toxic effects of CMA3 in the mouse model, a total of eight 6-8 week-old male Balb/c Rag-2/Jak3 double deficient mice (35) were randomly separated into 4 groups ( $n=2 /$ group; body weight 22-25 g/mouse); group 1 was intravenously injected with a vehicle, dimethyl sulfoxide (DMSO) once a week, group 2 was injected with $0.1 \mathrm{mg} / \mathrm{kg}$ CMA3 once a week, group 3 was injected with $0.1 \mathrm{mg} / \mathrm{kg} \mathrm{CMA} 3$ twice a week and group 4 was injected with $0.5 \mathrm{mg} / \mathrm{kg} \mathrm{CMA} 3$ once a week. The vehicle or CMA3 was given for 3 weeks. The toxicity was monitored by observation of the general appearance and determination of the body weight.

Xenograft mouse model. KKU-213 cells (1x10 5 cells/site) were subcutaneously injected into both flanks of 6-8 week-old male Balb/c Rag-2/Jak3 double deficient mice. At 3 days after CCA injection, 14 mice were randomly divided into 2 groups ( $\mathrm{n}=7 /$ group; body weight $\sim 22-25 \mathrm{~g} / \mathrm{mouse}$ ). CMA3 was administered to the treatment group at $0.5 \mathrm{mg} / \mathrm{kg}$ intravenously, once a week for 3 weeks. DMSO was given to the control group. Body weight and tumor volume were monitored every 3 days. On day 22, mice were sacrificed and tumors were collected for the immunohistochemistry staining.

Mice were housed and monitored in the animal research facility according to the institutional guidelines. All protocols were approved by the Institutional Animal Care and Use Committee of Kumamoto University. All of the animal experiments were conducted according to the Fundamental Guidelines for Proper Conduct of Animal Experiment and
Related Activities in Academic Research Institutions under the jurisdiction of the Ministry of Education, Culture, Sports, Science and Technology, Japan. In brief, mice were housed in a strictly control environment $\left(22 \pm 2^{\circ} \mathrm{C}\right.$, $50 \pm 10 \%$ humidity and 12-h light/dark cycle). Food and water were provided ad libitum. Health and behavior of those mice were monitored every 3 days to evaluate humane endpoints. If mice showed loss of appetite, severe weight loss ( $>20 \%$ of the original weight) or signs of pain associated behavior, mice would be euthanized using isoflurane. Death was verified as follows: Lack of respiration, heartbeat and corneal reflex. A total of $5 \%$ inhaled isoflurane was used as an anesthetic.

Immunohistochemistry. Paraffin embeded xenograft tumor tissues were prepared according to a standard protocol (36) and sectioned at 3- $\mu \mathrm{m}$ thickness. Expression of cytokeratin, Ki-67 and $\alpha$-SMA were detected using BenchMark XT automated staining system (Ventana Medical Systems, Inc.). EZ prep, Cell conditioning (CC1) and Inhibitor CM (Ventana Medical Systems, Inc.) were used according to manufacturer's protocol. Images were taken by an Eclipse Ni-E light microscope (Nikon Corporation) using NIS Elements D software version 4.5 (Nikon Corporation). Ki-67 positive nuclei per cytokeratin areas were quantified by ImageJ ( $n=4 /$ group, 3 images/tumor).

Caspase-9, CK19 and Bax expression was determined by immunohistochemistry as previously described (37). The caspase- 9 or Bax-positive areas were determined by ImageJ ( $n=5 /$ group, 5 images/tumor). The expression of caspase- 9 or Bax was presented as the marker-positive area/CK19-positive nuclei/cancer area.

Statistical analysis. The data are presented as the mean \pm standard deviation from three independent experiments unless otherwise specified. The statistical differences between the control and experimental groups were determined by Student's t-test. For CMA3 toxicity testing, mean percentage of body weights among the groups were analyzed using one-way analysis of variance with Tukey's post hoc test. $\mathrm{P}<0.05$ was considered to indicate a statistically significant difference. Statistical analyses were performed using the GraphPad Prism software version 8 (GraphPad Software, Inc.) and SPSS software version 19.0 (IBM, Corp.).

\section{Results}

CMA3 and MTA inhibit CCA cell proliferation. Effects of CMA3 and the prototype drug, MTA, on cell proliferations of 3 CCA cell lines, KKU-213, KKU-055 and KKU-100, were determined by MTT assay. Cells were treated with increasing concentrations of CMA3 or MTA for 24 and $48 \mathrm{~h}$. The dose-response curves revealed CMA3 and MTA suppressed CCA cell proliferation in dose- and time-dependent manners (Fig. 1). The half maximal inhibitory concentrations $\left(\mathrm{IC}_{50 \mathrm{~s}}\right)$ of CMA3 on KKU-213 at 24 and $48 \mathrm{~h}$ were $22.48 \pm 4.08$ and $9.79 \pm 1.15 \mathrm{nM} ; \mathrm{IC}_{50 \mathrm{~s}}$ of KKU-055 were $21.14 \pm 2.24$ and $13.34 \pm 1.28 \mathrm{nM}$; and $\mathrm{IC}_{50 \mathrm{~s}}$ of KKU-100 were $30.52 \pm 2.91$ and $14.74 \pm 1.34 \mathrm{nM}$. The $\mathrm{IC}_{50 \mathrm{~s}}$ of MTA were higher than those of CMA3; $\mathrm{IC}_{50 \mathrm{~s}}$ of KKU-213 at 24 and $48 \mathrm{~h}$ 
Table I. $\mathrm{IC}_{50 \mathrm{~s}}$ of CMA3 and MTA for three CCA cell lines at 24 and $48 \mathrm{~h}$.

\begin{tabular}{lcccc}
\hline & \multicolumn{2}{c}{ CMA3 } & & \multicolumn{2}{c}{ MTA } \\
\cline { 2 - 4 } Cell lines & $24 \mathrm{~h}$ & $48 \mathrm{~h}$ & $24 \mathrm{~h}$ & $48 \mathrm{~h}$ \\
\hline KKU-213 & $22.48 \pm 4.08$ & $9.79 \pm 1.15$ & $>200$ & $46.08 \pm 1.63$ \\
KKU-055 & $21.14 \pm 2.24$ & $13.34 \pm 1.28$ & $>200$ & $76.44 \pm 11.70$ \\
KKU-100 & $30.52 \pm 2.91$ & $14.74 \pm 1.34$ & $>200$ & $104.77 \pm 4.22$ \\
\hline
\end{tabular}

$\mathrm{IC}_{50 \mathrm{~s}}$ are presented as the mean \pm standard deviation (in $\mathrm{nM}$ ). $\mathrm{IC}_{50 \mathrm{~s}}$, half maximal inhibitory concentrations; CMA3, Chromomycin A3; MTA, mithramycin A.

A

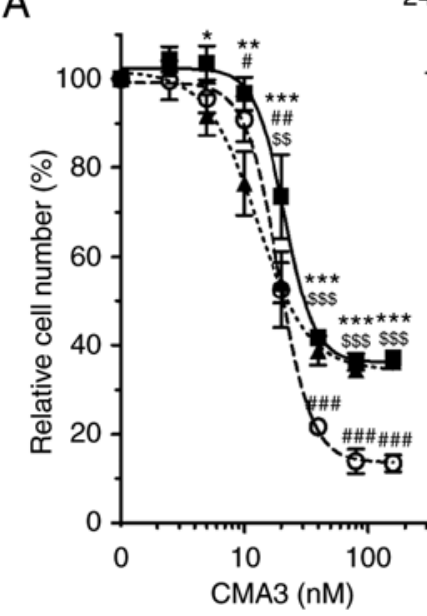

$24 \mathrm{~h}$

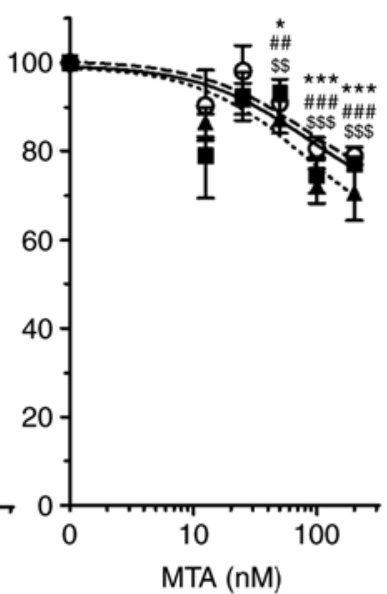

B

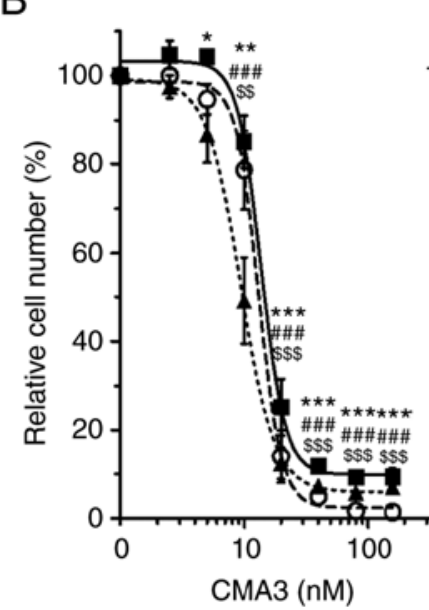

$48 \mathrm{~h}$

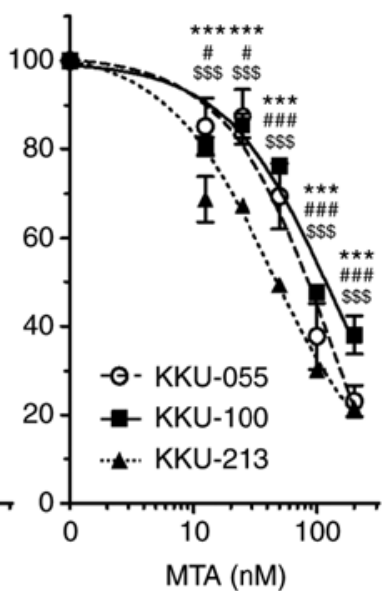

Figure 1. CMA3 and MTA inhibit CCA cell proliferation in dose- and time-dependent manners. Anti-proliferative effects of CMA3 and MTA on three CCA cell lines were determined by MTT assay. KKU-213, KKU-055 and KKU-100 were treated with increasing concentrations of CMA3 (0, 2.5, 5, 10, 20, 40, 80 and $160 \mathrm{nM})$ or MTA $(0,12.5,25,50,100$ and $200 \mathrm{nM})$ for (A) 24 and (B) $48 \mathrm{~h}$. Data are represented as the mean \pm standard deviation from three independent experiments. The statistical significances of each cell line compared with the control are shown as follows: ${ }^{*} \mathrm{P}<0.05$, ${ }^{* *} \mathrm{P}<0.01$ and ${ }^{* * * *} \mathrm{P}<0.001 \mathrm{vs}$. $0 \mathrm{nM}$ for KKU-213 cells; ${ }^{\# P} \mathrm{P}<0.05,{ }^{\# \#} \mathrm{P}<0.01$ and ${ }^{\# \# \#} \mathrm{P}<0.001$ vs. $0 \mathrm{nM}$ for KKU-005 cells; ${ }^{\$ \$} \mathrm{P}<0.01$ and ${ }^{\$ \$} \$ \mathrm{P}<0.001$ vs. 0 nM for KKU-100 cells. CMA3, chromomycin A3; MTA, mithramycin A; CCA, cholangiocarcinoma.

were $>200$ and $46.08 \pm 1.63 \mathrm{nM} ; \mathrm{IC}_{50 \mathrm{~s}}$ of KKU-055 were $>200$ and $76.44 \pm 11.70 \mathrm{nM}$; and $\mathrm{IC}_{50 \mathrm{~s}}$ of KKU-100 were $>200$ and $104.77 \pm 4.22 \mathrm{nM}$ (Table I).

CMA3 promotes $S$ phase arrest in $K K U-213$ and $K K U-055$. CMA3 is a DNA-binding agent that binds to DNA at a minor groove and inhibits DNA replication and transcription (26). To verify the effects of CMA3 on cell cycle distribution, KKU-213 and KKU-055 were treated with 0,2.5, 5, and $10 \mathrm{nM} \mathrm{CMA3} \mathrm{for}$ 24 h. Cells were stained with PI and the cell cycle distributions were analyzed by flow cytometry. The results showed increased concentrations of CMA3 significantly increased cells in the $\mathrm{S}$ phase. Fig. 2A shows the representative histograms. CMA3 caused the accumulation of cells in $\mathrm{S}$ phase, while the reduction of cells in G1 phase was observed (Fig. 2A). A total of $42.5 \pm 1.7,45.8 \pm 0.9,50.4 \pm 5.9$ and $62.8 \pm 2.4 \%$ of KKU-213 and $50.0 \pm 2.6,53.2 \pm 1.9,64.9 \pm 8.1$ and $74.6 \pm 3.3 \%$ of KKU-055 were in $\mathrm{S}$ phase of the cell cycle when cells were treated with $0,2.5$, 5, and 10 nM CMA3 ( $\mathrm{P}<0.05$ and $\mathrm{P}<0.001$; Fig. 2B).

CMA3 induces caspase-dependent apoptosis in CCA cells. To investigate the effect of CMA3 on apoptotic induction,
Annexin V/PI staining was performed in KKU-213, KKU-055 and KKU-100 cells after treatment with 0, 10, 20 and $40 \mathrm{nM}$ of CMA3 for $24 \mathrm{~h}$. Annexin V and PI stained cells were evaluated by flow cytometry. Annexin V-positive and PI-negative cells were early apoptotic cells, whereas Annexin V and PI double-positive cells were late apoptotic. The percentages of early and late apoptotic cells were dramatically increased when cells were treated with higher concentrations of CMA3 (Fig. 3A). The percentages of Annexin V-positive cells were quantified by combining of percentages of early and late apoptotic cells and are presented in Fig. S1A and B $(\mathrm{P}<0.05)$. The results showed increased percentages of apoptotic cells in all three CCA cell lines in a dose-dependent manner. To elucidate the mechanism of CMA3-induced apoptosis, caspase activations were investigated. Caspase- $8,-9$ and -3 were selected to be the representatives of the extrinsic, intrinsic and common apoptotic pathways (38). The results demonstrated CMA3 induced caspase-dependent apoptosis in KKU-213 through both extrinsic (cleaved caspase-8), intrinsic (cleaved caspase-9) and eventually common (cleaved caspase-3) pathways in doseand time-dependent manners (Fig. 3B and 3C). Similar results of CMA3-induced caspase-dependent apoptosis were observed 
A

CMA3 (nM)
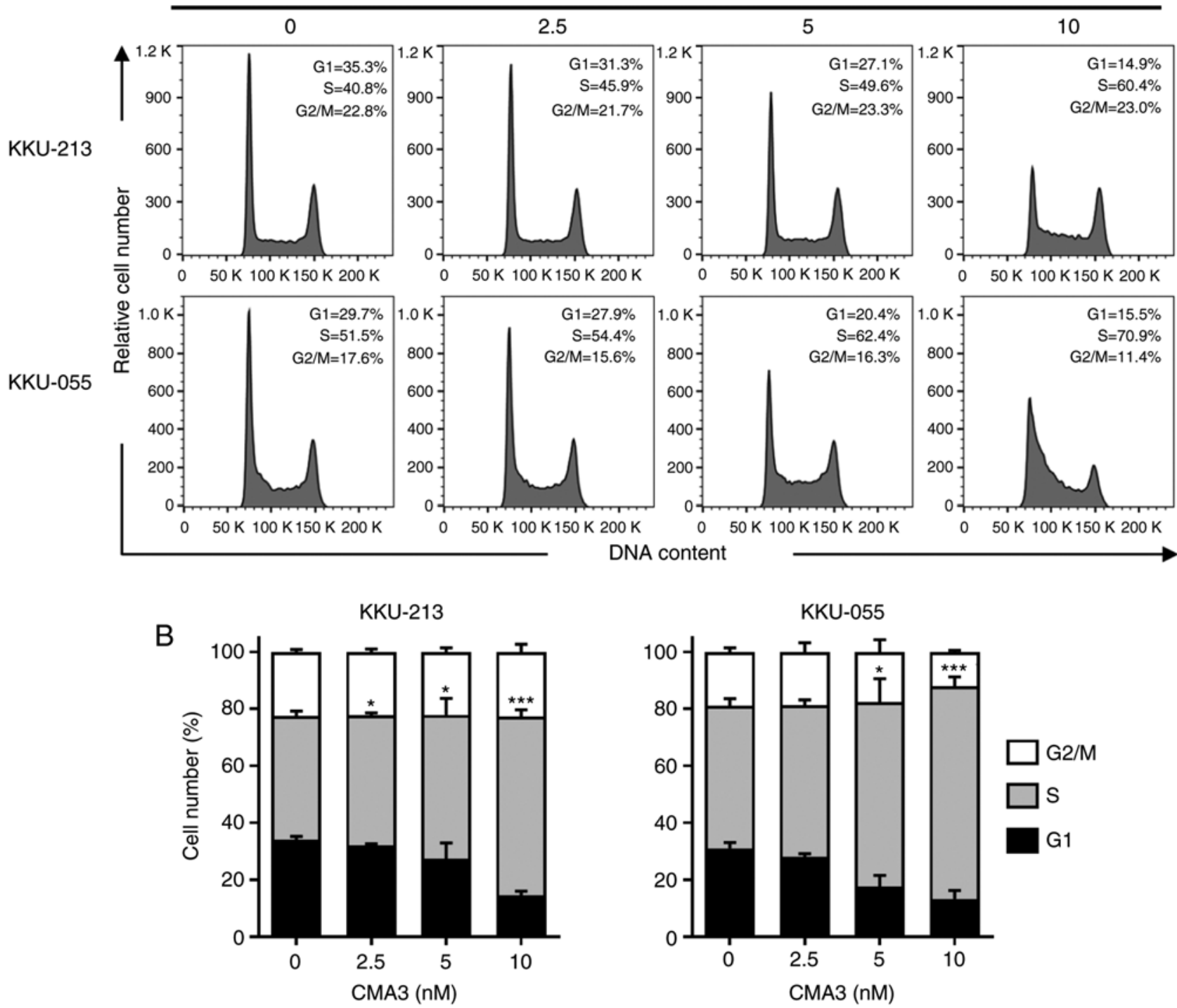

Figure 2. CMA3 promotes S phase arrest in CCA cells. (A) Representative flow cytometric profiles of KKU-213 and KKU-055 are demonstrated. Cells were treated with indicated concentrations of CMA3 $(0-10 \mathrm{nM})$ for $24 \mathrm{~h}$. DNA content was determined using propidium iodide staining and the distribution of the cell cycle was assessed by flow cytometry. (B) The graph represents the percentage of cells in each phase of cell cycle. The mean \pm standard deviation from three independent experiments are demonstrated. ${ }^{*} \mathrm{P}<0.05$ and ${ }^{* * *} \mathrm{P}<0.001$ vs. $0 \mathrm{nM}$ for $\mathrm{S}$ phase. CMA3, Chromomycin A3; CCA, cholangiocarcinoma.

in KKU-055 (Fig. S2A and B). Increased cleaved caspase-8, -9 and -3 levels were observed when cells were treated with 10-20 nM CMA3, with the highest levels observed following $12 \mathrm{~h}$ of $20 \mathrm{nM}$ CMA3 treatment.

CMA3 downregulates Spl-related anti-apoptotic proteins in $K K U-213$ and $K K U-055$. CMA3 is a structural analog of MTA. GC-rich, Sp1/Sp3-specific binding of MTA and CMA3 are established in neurons (20). Moreover, the roles of MTA on inhibition of Sp1 binding to the XIAP promoter and caspase-dependent apoptosis induction have been demonstrated in various cancer cells (17). Functions of CMA3 on Sp1-related anti-apoptotic protein expression were of interest. Sp1-related anti-apoptotic proteins including FLIP, cIAP2, Mcl-1, survivin and XIAP were selected $(13,39,40)$. The results showed FLIP, cIAP2, Mcl-1, survivin and XIAP were reduced in KKU-213 cells treated with 40 nM CMA3 (Fig. 4A). CMA3 treatment had no effects on either Sp1 or Sp1-related
Bcl-2 family pro-apoptotic proteins, e.g., Bcl-2-associated X-protein, Bax, Bcl-2-like protein 11, Bim and Noxa (Fig. 4B and $4 \mathrm{C}$ ). The quantitative analysis of Sp1, Sp1-related proteins was reported in Fig. 4D. Similar effects of CMA3-suppressed Sp1-related anti-apoptotic proteins were observed in KKU-055 when treated with $20 \mathrm{nM} \mathrm{CMA3}$ (Fig. S2C). The inhibitory effects of CMA3 and MTA on $\mathrm{Mcl}-\mathrm{l}$ and XIAP expression were confirmed by RT-PCR. KKU-213 cells were treated with $40 \mathrm{nM}$ CMA3 or $200 \mathrm{nM}$ MTA for the indicated times and then the expression levels of $\mathrm{Mcl}-1$ and XIAP were measured. The results showed CMA 3 and MTA efficiently inhibited Mcl-1 and XIAP expression and the reductions of expression were observed at $6 \mathrm{~h}$ onward. Moreover, CMA3 possessed a stronger effect on $\mathrm{Mcl}-1$ expression (Fig. S3).

CMA3 suppresses CCA growth and induces apoptosis in the xenograft mouse model. To determine the therapeutic potential of CMA3 on CCA in vivo, KKU-213 cells were 
A

CMA3 (nM)

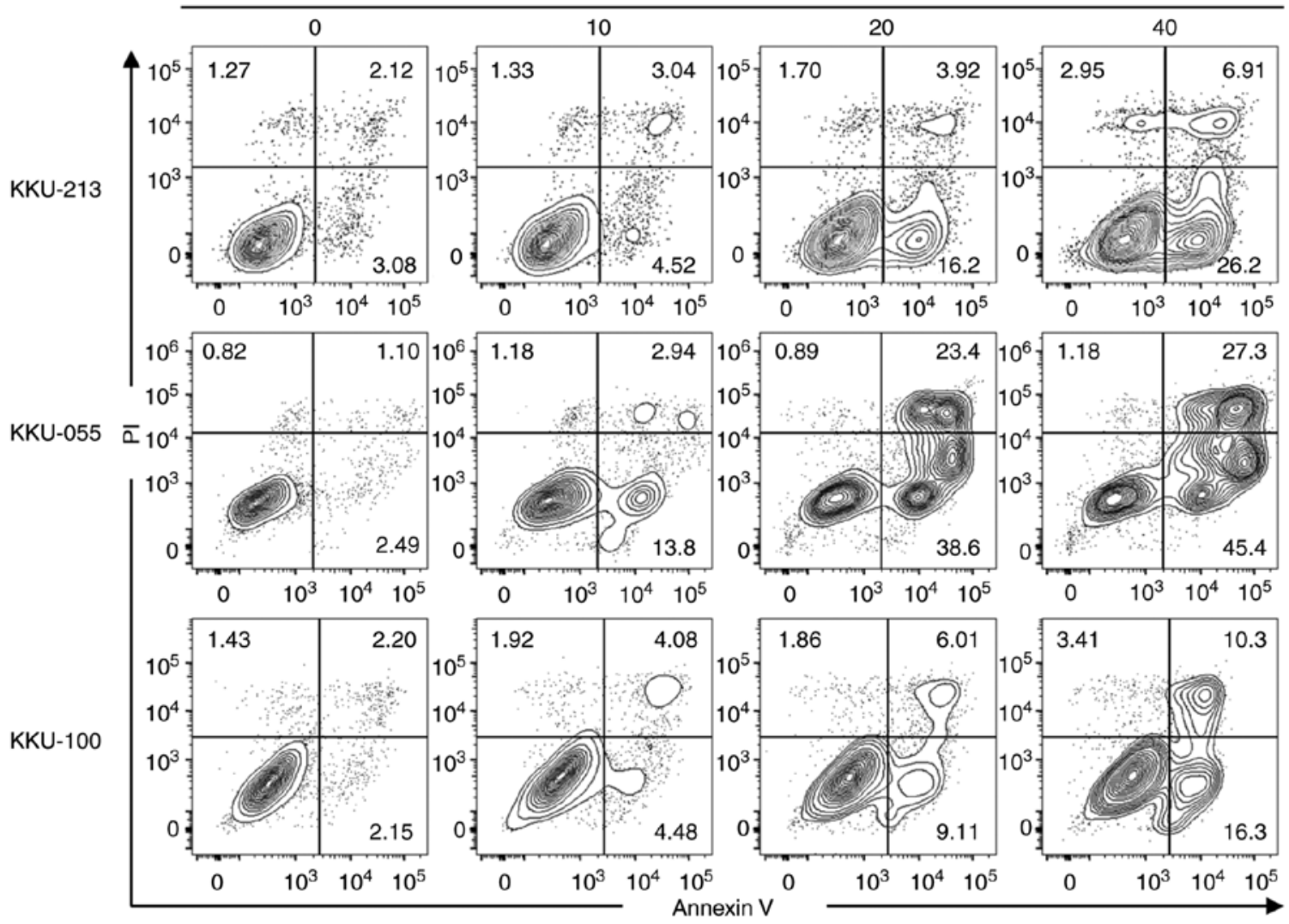

B
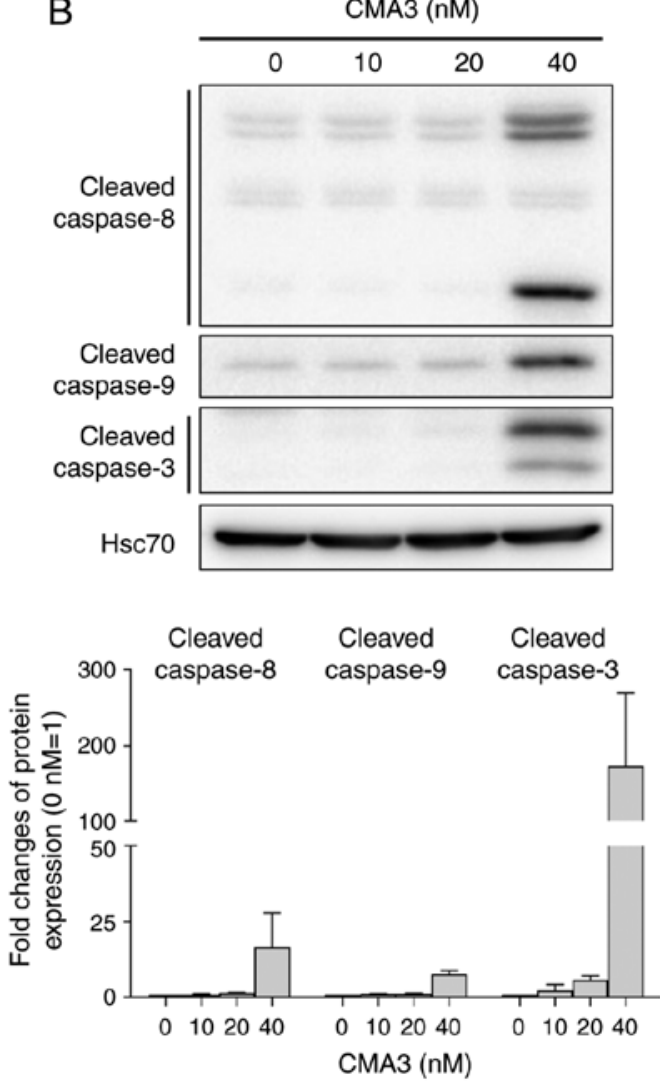

C
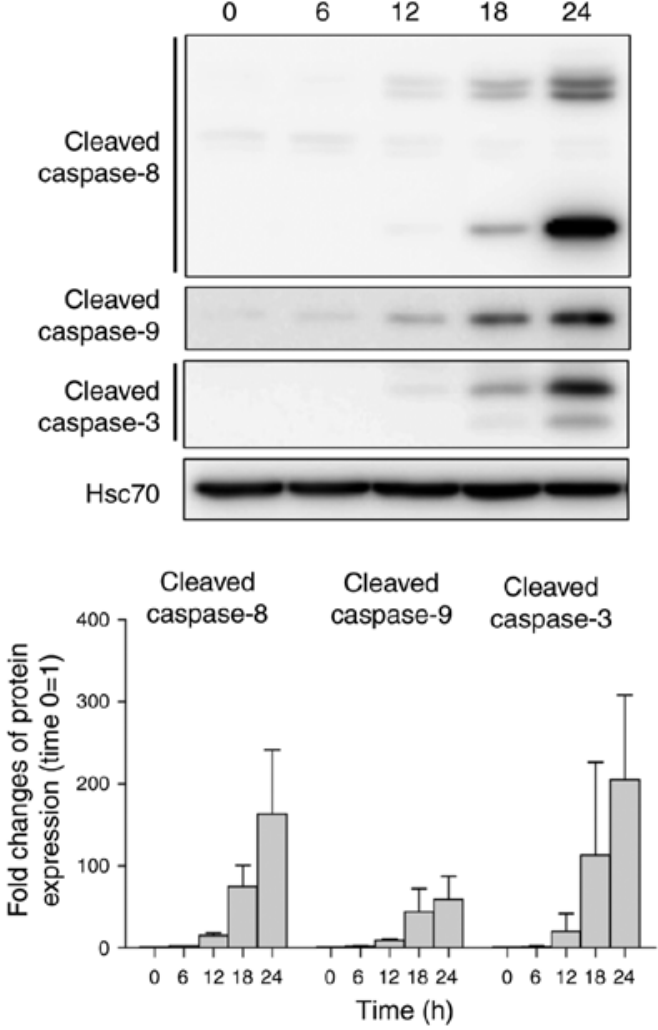

Figure 3. CMA3 induces caspase-dependent apoptosis in CCA. (A) CCA cells were treated with indicated concentrations of CMA3 for 24 h. Then cells were stained with Annexin V/PI and apoptotic cells were analyzed by flow cytometry. A representative image from three independent experiments is shown. The caspase activations in KKU-213 are demonstrated by western blotting. (B) Cells were treated with various concentrations of CMA3 for $24 \mathrm{~h}$ and (C) cells were treated with $40 \mathrm{nM}$ of CMA3 for indicated times. Intensities of protein bands were normalized with Hsc70 and compared with those without CMA3 (0 nM or $0 \mathrm{~h}$, intensity=1). The normalized intensities of caspase expression from three independent experiments were shown. CMA3, Chromomycin A3; CCA, cholangiocarcinoma; PI, propidium iodide. 
A

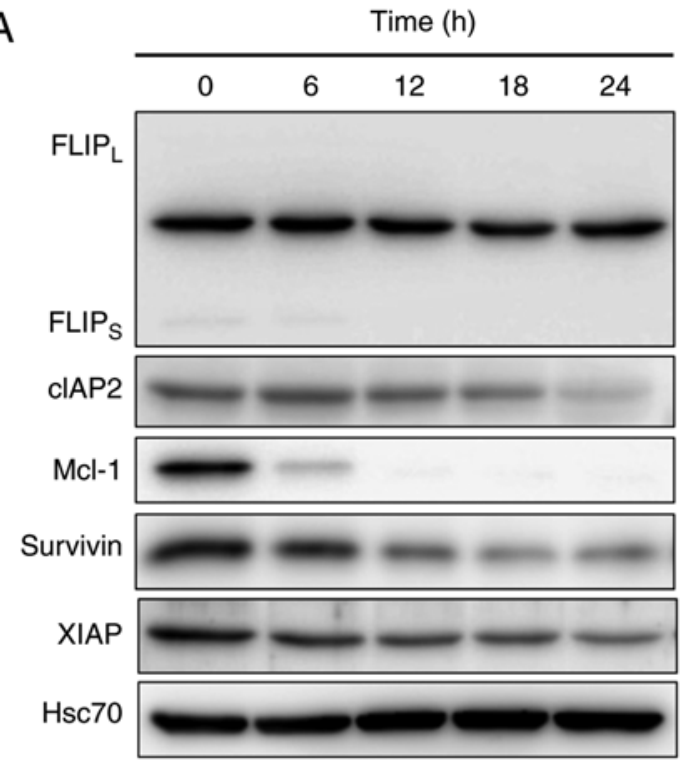

B

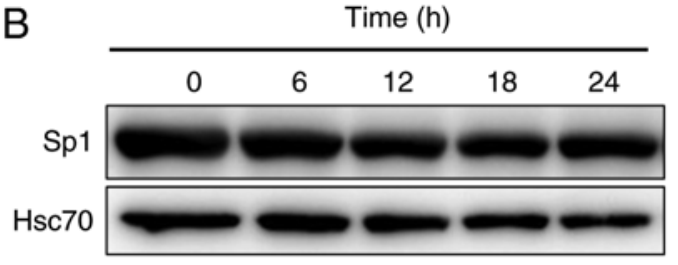

C

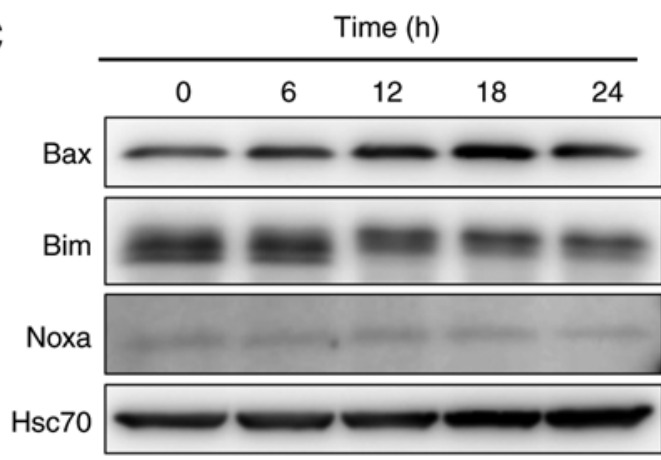

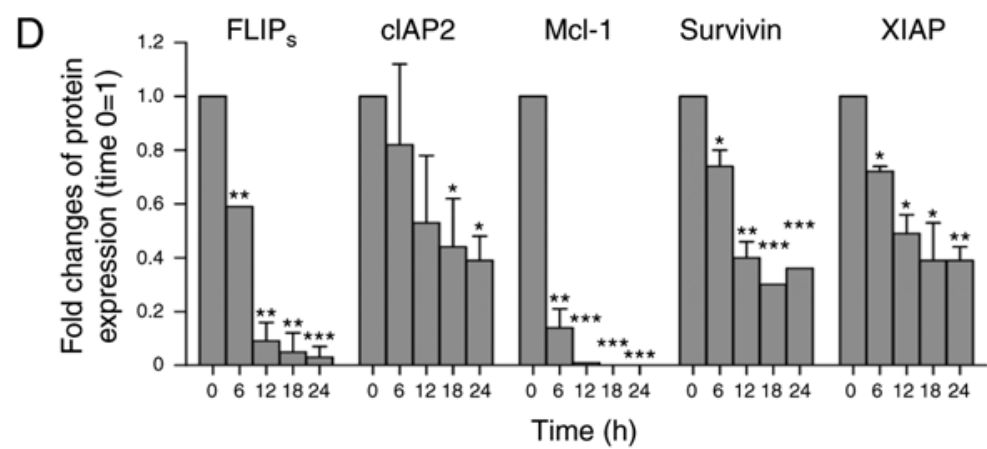

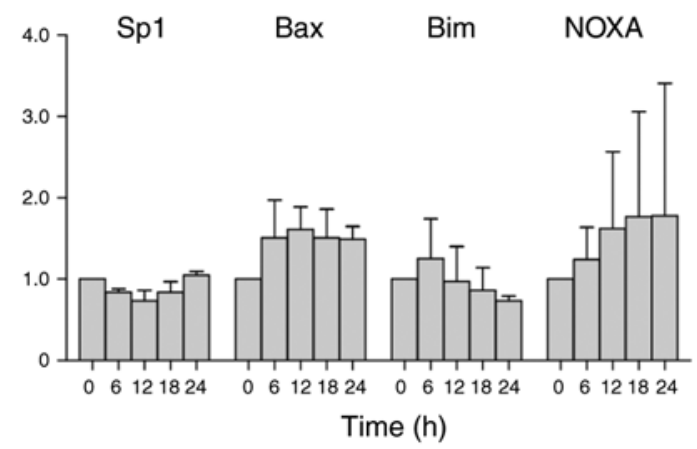

Figure 4. CMA3 induces apoptosis in CCA cells via downregulation of Sp1-related anti-apoptotic proteins. KKU-213 was treated with 40 nM CMA3 for 0-24 h. (A) The expression of Sp1-related anti-apoptotic proteins: FLIPs, cIAP2, Mcl-1, survivin and XIAP was demonstrated by western blotting. (B) The expression of Sp1 transcription factor and (C) pro-apoptotic proteins; Bax, Bim and Noxa, is revealed. Intensities of protein bands were normalized with Hsc70 and compared relative to those without CMA3 $(0 \mathrm{~h}=1)$. (D) Normalized intensities of Sp1 and Sp1-related protein expression from three independent experiments were shown. For $\mathrm{FLIP}_{\mathrm{S} / \mathrm{L}}$, only the $\mathrm{FLIP}_{\mathrm{S}}$ isoform was quantitated. CMA3, Chromomycin A3; CCA, cholangiocarcinoma; Sp1, specificity protein 1; FLIP, FADD-like IL-1 $\beta$-converting enzyme-inhibitory protein; cIAP2, cellular inhibitor of apoptosis; XIAP, X-linked inhibitor of apoptosis protein; Mcl-1, myeloid cell leukemia-1. ${ }^{*} \mathrm{P}<0.05,{ }^{* *} \mathrm{P}<0.01,{ }^{* * * *} \mathrm{P}<0.001$ vs. $0 \mathrm{~h}$.

injected subcutaneously into flanks of Balb/c RJ mice. Mice were randomly assigned to the control and CMA3-treated groups and the treatments were given for 3 weeks. No noticeable toxicity of CMA3 was observed during the experiment (Fig. S4C), which corresponded with the results of the CMA3 toxicity test (Fig. S5). Tumor volumes were measured. The results demonstrated that on day 22 , the tumor volumes of the treatment group were significantly smaller than those of the control group $\left(\mathrm{P}<0.001 ; 178.3 \pm 89.4\right.$ vs. $476.0 \pm 174.7 \mathrm{~mm}^{3}$; Fig. 5A). All mice were subsequently euthanized and xenograft tumors were weighed. The average tumor weights of the CMA3-treated group were significantly decreased compared with control $(\mathrm{P}<0.05 ; 0.34 \pm 0.22$ vs. $0.56 \pm 0.20 \mathrm{~g}$; Fig. S4A and B). Moreover, when tumors were removed, they were then examined for the densities of cancer and stromal cell compartments. Ki-67 was used as proliferative marker, while pancytokeratin and $\alpha$-SMA were used as epithelial (CCA) and active stromal markers. Ki-67 nuclei/cytokeratin-positive areas were assessed and compared between groups. The results demonstrated that the $\mathrm{Ki}-67 /$ cytokeratin-positive areas were smaller in the CMA3-treated group when compared with the control group $[\mathrm{P}<0.001 ; 1.02 \pm 0.17$ vs. $0.75 \pm 0.15$ nuclei/arbitrary units (AU); Fig. 5B]. Representative images of Ki-67, pancytokeratin and $\alpha$-SMA staining are shown in Fig. 5C.

The effects of CMA3 on the apoptotic proteins, caspase-9 and Bax, were determined in xenograft tumors. The results revealed that CMA3 treatment potentiated caspase-9 and Bax expression (Fig. 5D). The expression of caspase-9 and Bax in the CMA3-treated group were significantly increased compared with DMSO-treated control; caspase-9 expression were 3.25 \pm 1.10 vs. $2.14 \pm 0.76$ in control and Bax were $3.60 \pm 0.95$ vs. $2.86 \pm 1.16$ in control $(\mathrm{P}<0.05$ and $\mathrm{P}<0.001 ;$ AU/cells/field; Fig. S6).

\section{Discussion}

CCA is an aggressive cancer, in which patients are often diagnosed at the advanced stages and curative surgery is not an option (4). Several chemotherapies have been tried to improve the clinical outcome (41). Nevertheless, the efficacies of the treatments are restricted by CCA chemoresistance (5). Increased expression of multiple anti-apoptotic proteins including Bcl-2, Bcl-xL, FLIP, cIAP, Mcl-1, survivin and 

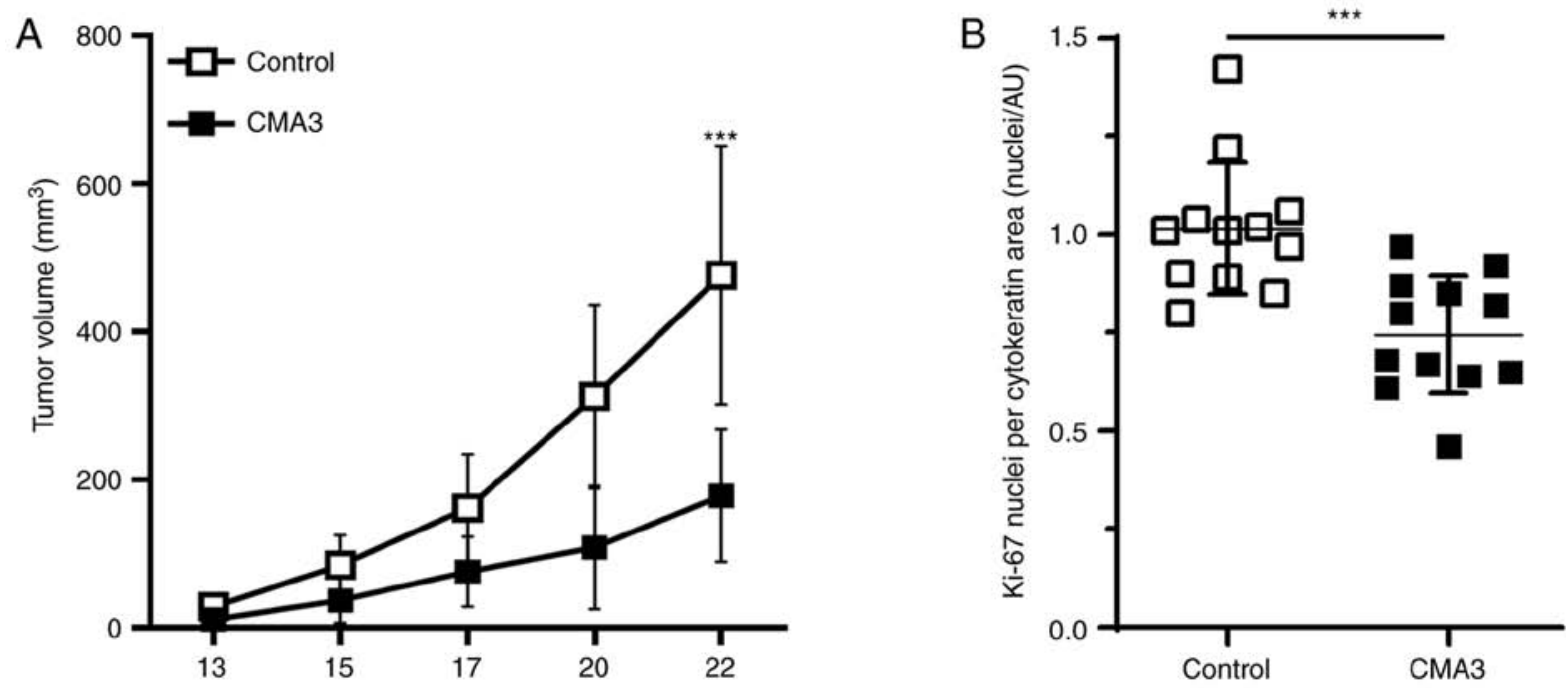

C

$\mathrm{Ki}-67$

Pancytokeratin
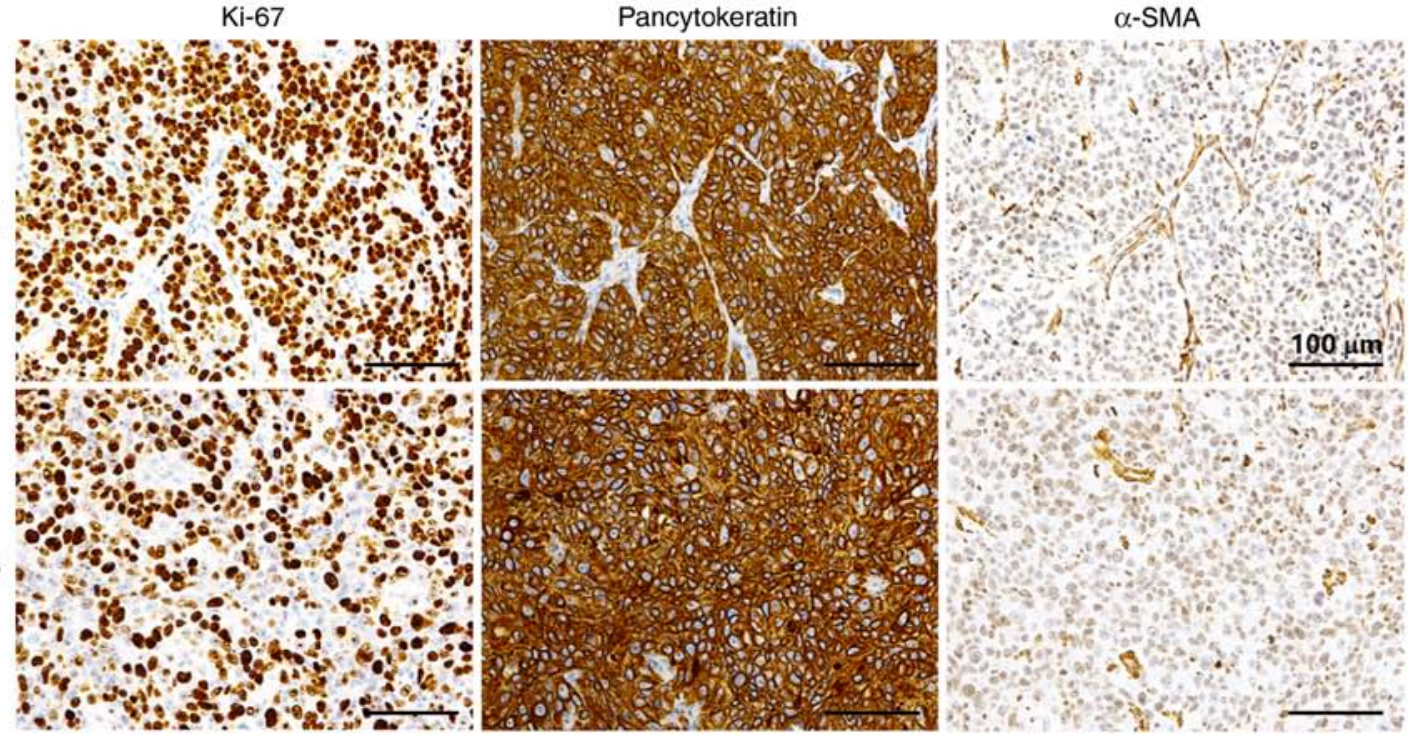

D

Cytokeratin 19
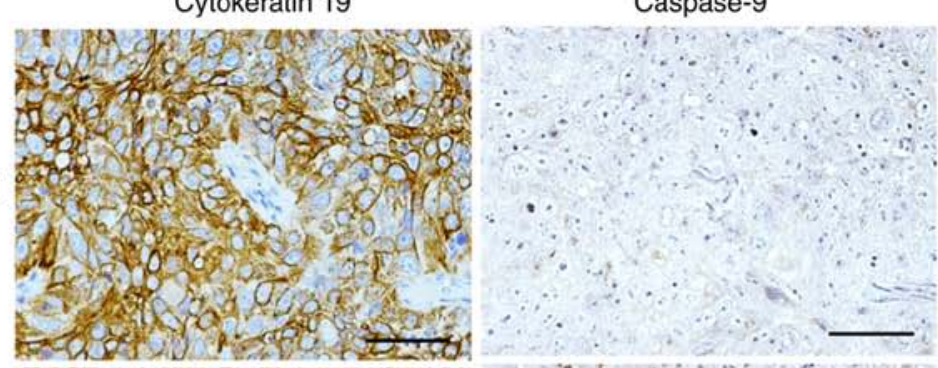

Caspase- 9

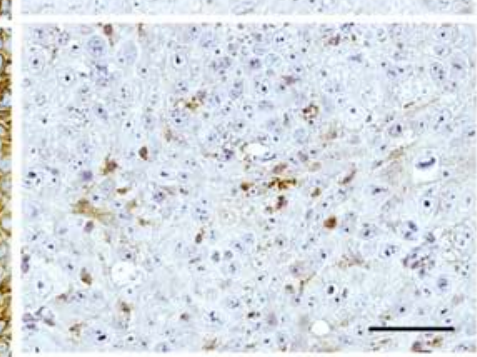

Bax

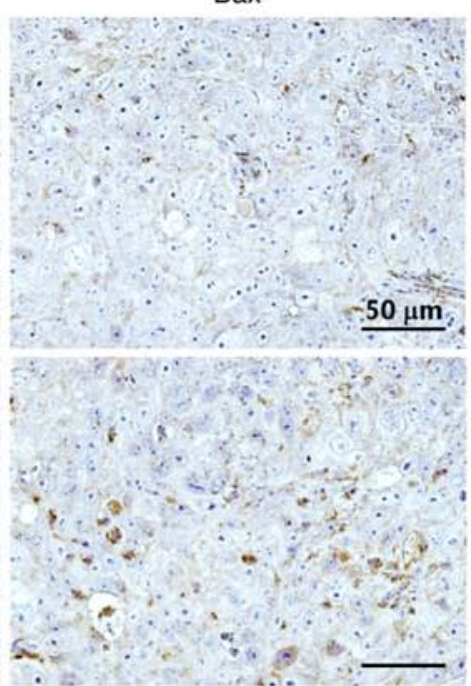

Figure 5. CMA3 suppresses CCA growth and induces apoptosis in the xenograft mouse model. KKU-213 cells were subcutaneously injected into both flanks of Balb/c RJ mice. CMA3 was administered at $0.5 \mathrm{mg} / \mathrm{kg}$ into the tail vein once a week for 3 times. Control mice were treated with DMSO. Mice were euthanized on day 22 of the experiment. (A) Tumor volumes were measured every 3 days and are represented as the mean \pm SD. ${ }^{* * * *} \mathrm{P}<0.001$. (B) The numbers of Ki-67-positive nuclei per pancytokeratin-positive areas were compared between the control and CMA3-treated groups $(\mathrm{n}=4 / \mathrm{group}, 3 \mathrm{images} / \mathrm{tumor}$, total=12 images/group). Data are presented as the mean $\pm \mathrm{SD}$. ${ }^{* * *} \mathrm{P}<0.001$. (C) Representative Ki-67, pancytokeratin and $\alpha$-SMA immunohistochemistry staining of the control and CMA3-treated tumors are shown. Scale bar=100 $\mu \mathrm{m}$. (D) Cytokeratin 19, caspase-9 and Bax expression in representative areas from the control and CMA3-treated groups. Scale bar=50 $\mu \mathrm{m}$. SD, standard deviation; CMA3, Chromomycin A3; CCA, cholangiocarcinoma; SMA, smooth muscle actin. 


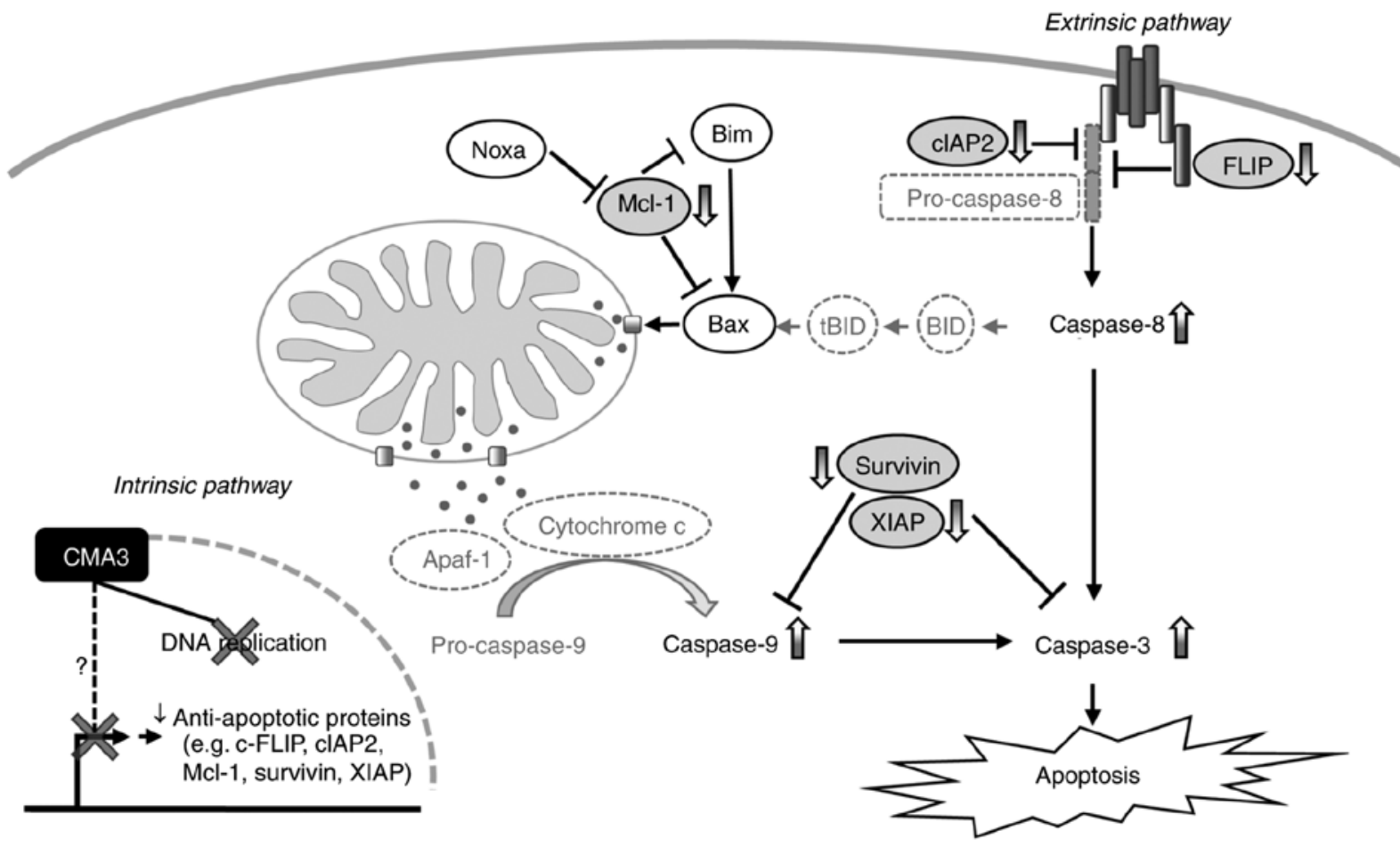

Figure 6. Proposed mechanism of CMA3 suppressing CCA growth through the downregulation of Sp1-related anti-apoptotic proteins. Downregulation of Sp1-related anti-apoptotic proteins promotes the apoptotic cascade through caspase activation. Upward and downward arrows indicate the upregulated and downregulated apoptosis-related proteins in CMA3-treated CCA cells. CMA3, Chromomycin A3; Sp1, specificity protein 1; CCA, cholangiocarcinoma; FLIP, FADD-like IL-1 $\beta$-converting enzyme-inhibitory protein; cIAP2, cellular inhibitor of apoptosis; XIAP, X-linked inhibitor of apoptosis protein; Mcl-1, myeloid cell leukemia-1.

XIAP have been reported accompanied by acquired chemoresistance $(8-12,42)$. The potential role of anti-apoptotic protein modulation on CCA treatment was demonstrated in the present study using CMA3 as a candidate. CMA3 effectively inhibited CCA cell proliferation in the nanomolar ranges and the effects were stronger than the prototype drug, MTA. The DNA binding property of CMA3 (19) contributed to cell cycle arrest in the $\mathrm{S}$ phase in doses lower than $\mathrm{IC}_{50}$. That CMA3 promoted CCA apoptosis was demonstrated. This was partially proven through Sp1-related anti-apoptotic protein suppression, e.g., FLIP, cIAP2 Mcl-1, survivin and XIAP, and caspase activation. The benefit of CMA3 treatment on CCA was established in a xenograft model. Suppression of CCA growth was demonstrated histologically and grossly. To the best of the authors' knowledge, this is the first study to demonstrate Sp1-related anti-apoptotic protein suppression leading to apoptotic induction and suppression of tumor growth by CMA3.

The anti-cancer effects of CMA3 were previously reported in cancer $(23,24,27)$. CMA3 has been tried in a phase 1 clinical trial in patients with breast cancer, Hodgkin's disease, lung adenocarcinoma, melanoma and rhabdomyosarcoma but the results were inconsistent in tolerable doses and side effects $(23,24)$. The suspected toxicity might have led to 2 patient deaths (24), however, it has been put to an alternative use as DNA staining dye (25). Currently, the repurposing program in oncology has provided an opportunity for previously tested agents such as CMA3 (43). The anti-proliferation of CMA3 was previously reported in cervical cancer cells, ME180 and HeLa (27). It is worth mentioning that the stronger effects of CMA3 were observed in the current study. The $\mathrm{IC}_{50 \mathrm{~s}}$ in cervical cancer cells were 4-10 times higher. The differences could be affected by the different assessments; ATP quantitation, as reported by Miller et al (27) and mitochondrial enzyme activity in the present study. This requires further attention and was beyond the scope of this study.

The roles of CMA3 in CCA inhibition have been explored. CCA cells treated with CMA3 were accumulated at the $\mathrm{S}$ phase of the cell cycle. The effects of CMA3 on the cell cycle have never been reported to the best of our knowledge. There is a report that chromomycin A2, a CMA3 analog, inhibits the melanoma cell cycle at the G0/G1 phase (44). This effect was related to the induction of cyclin D1 and D3 and the suppression of cyclin A2 and B1. By comparison, no significant alteration was observed in CMA3 treated melanoma. The discrepancy of CMA analogs on the cell cycle might be due to the DNA binding specificities (20). The functions of CMA3 in cell cycle control in cancer require further investigation. CMA3-induced CCA apoptosis was demonstrated in the present study. CMA3 induced phosphatidylserine exposure and caspase- $8,-9$, and -3 activations. CMA3-promoted caspase-3/7 activation was previously demonstrated in cervical cancer (27). CMA3 activated caspase-8, -9 and -3-related apoptotic induction was observed in MTA-treated cervical cancer (18). Activations of both extrinsic and intrinsic apoptotic pathways were first demonstrated in the current study, to the best of our knowledge.

Mechanisms in which CMA3-induced apoptosis were proposed to be Sp1-related based on the mechanism of the structurally related agent, MTA $(17,18)$. Sp1-related anti-apoptotic proteins; FLIP, cIAP2, Mcl-1, survivin and XIAP, were selected candidates $(13,39,40)$. The results showed 
CMA3 suppressed certain Sp1-related anti-apoptotic proteins. These alterations were not observed in Sp1 and Sp1-related pro-apoptotic proteins; Bax, Bim, and Noxa. The inhibitory effects of CMA3 and MTA on Sp1-related anti-apoptotic gene expression were confirmed by determination of $\mathrm{Mcl}-\mathrm{I}$ and XIAP mRNA expression in CMA3- or MTA-treated KKU-213. The results corresponded to the previous report that CMA3 possesses stronger DNA binding activity than MTA $(19,20)$. The potent inhibition was observed on $\mathrm{Mcl}-\mathrm{I}$ expression. It is worth mentioning that the expression of XIAP in CMA3-treated KKU-213 rebounded to the original state at $24 \mathrm{~h}$. The differential effects of CMA3 on $\mathrm{Mcl}-1$ and XIAP promoter bindings and expression require further investigation. The effects of MTA on XIAP suppression were demonstrated in renal carcinoma (Caki), colon cancer (HT29), breast cancer (MDA321), prostate cancer (PC3) and astroglioma (U87) (17). The similar effects of MTA and CMA3 on XIAP expression were proposed through the inhibition of Sp1 binding on the promoter. The role of MTA on Sp1 expression at mRNA and protein levels were previously reported in cervical cancer cells, HEp-2 and KB, (18) but it was not observed in the current study. This might be due to the higher concentrations $\left(\mathrm{IC}_{70}-\mathrm{IC}_{90} \mathrm{vs}\right.$. $\mathrm{IC}_{60}$ in this study) and the longer treatments (48 vs. $24 \mathrm{~h}$ in this study) than in the other studies. Longer treatments with higher drug concentrations might possess a stronger effect on Sp1 suppression.

Anti-CCA effects of CMA3 were supported by the xenograft model. Treatment with intravenous CMA3 to CCA-bearing mice inhibited tumor growth by inhibition of cell proliferation. Lower densities of Ki-67-positive CCA cells were observed in the treatment group. It is worth mentioning that larger nuclei were observed in the treatment group consistent with $S$ phase arrest observed in the cell cycle analysis. The growth inhibitory effects of CMA3 in vivo were partly due to apoptosis induction. Increased caspase- 9 and Bax expression in CMA3-treated tumors was demonstrated in the present study. Only 3 doses of CMA3 were administered to mice and no observable toxicity was noticed. Therefore, these results confirmed the potent anti-CCA effect of CMA3. The toxicity of CMA3 is of concern. From in vivo toxicity testing in the current study, no obvious effects were observed in mouse general well-being and body weights. In vitro toxicity testing using peripheral blood mononuclear cells or other normal cell types and the comparative study of CMA3 and MTA effects in vivo are required prior to a trial in patients. It is not possible in the current study due to limited resources.

The anti-cancer effect of CMA3 on CCA is summarized in Fig. 6. The proposed mechanism of how CMA3 inhibited CCA was through selective DNA binding, which resulted in 2 outcomes; i) inhibition of DNA replication, which later causes $\mathrm{S}$ phase arrest; ii) reductions of Sp1-related anti-apoptotic proteins (e.g., FLIP, cIAP2, Mcl-1, survivin and XIAP), which cause an imbalance between pro-apoptotic and anti-apoptotic signals, and subsequently promotes caspase activation and apoptotic induction. No significant alterations of Sp1 and Sp1-related pro-apoptotic proteins (e.g., Bax, Bim and Noxa) were observed in the current study. Altogether, the underlying mechanism in which CMA3-induced CCA apoptosis through alleviation of Sp1-related anti-apoptotic proteins was demonstrated for the first time in the current study. The mechanistic studies using an $\mathrm{Sp} 1$ reporter assay or immunoprecipitation might directly establish the effects of CMA3 and require further investigations. This may attenuate the chemoresistance of CCA to currently available chemotherapeutic drugs. The adjunct treatment with CMA3 or CMA3 derivatives might be a novel strategy for CCA treatment.

\section{Acknowledgements}

The authors would like to thank Ms Sawako Fujikawa and and Ms Yoshie Kanagawa (Division of Hematopoiesis, Joint Research Center for Human Retrovirus Infection, Kumamoto University) for their technical assistance and secretarial assistance, respectively.

\section{Funding}

The present study was supported in part by the Faculty of Medicine Khon Kaen University, Thailand (grant no. IN61304 to PS and KV), Khon Kaen University, Thailand (grant no. 6200020001 to KV) and Grant-in-Aid for Scientific Research from the Ministry of Education, Culture, Sport Science and Technology (MEXT) of Japan (grant no. 16K08742 to SO). PS was supported by a scholarship from the Graduate School, Khon Kaen University (grant no. 591H109) and by the student exchange support from the Japan Student Services Organization, Japan and the Study and Research in Abroad Scholarship of Khon Kaen University.

\section{Availability of data and materials}

All data generated or analyzed during this study are included in this published article.

\section{Authors' contributions}

PS, SO and KV made substantial contributions to the conception and design of the study, acquisition of data, and analysis of data. RK, GS, PB and TB performed experiments and interpreted data. KS, CW and SW contributed to the conception of the study and experimental design. PS, SO and KV drafted the article and critically reviewed it for the intellectual content. All authors approved the final version of the article. All authors agree to be held accountable for all aspects of the work in ensuring that questions related to the accuracy or integrity of the work are appropriately investigated and resolved.

\section{Ethics approval and consent to participate}

The study protocol was reviewed and approved by the Ethical Committee for the Human Research of Khon Kaen University (policy no. HE611034), based on the Declaration of Helsinki of 1975. All animal protocols were approved by the Institutional Animal Care and Use Committee of Kumamoto University (policy no. A 29-046), and conducted according to the Fundamental Guidelines for Proper Conduct of Animal Experiment and Related Activities in Academic Research Institutions under the jurisdiction of the Ministry of Education, Culture, Sports, Science and Technology, Japan. 


\section{Patient consent for publication}

Not applicable.

\section{Competing interests}

The authors declare that they have no competing interests.

\section{References}

1. Banales JM, Cardinale V, Carpino G, Marzioni M, Andersen JB, Invernizzi P, Lind GE, Folseraas T, Forbes SJ, Fouassier L, et al: Expert consensus document: Cholangiocarcinoma: Current knowledge and future perspectives consensus statement from the European network for the study of cholangiocarcinoma (ENS-CCA). Nat Rev Gastroenterol Hepatol 13: 261-280, 2016.

2. Sripa B, Bethony JM, Sithithaworn P, Kaewkes S, Mairiang E, Loukas A, Mulvenna J, Laha T, Hotez PJ, Brindley PJ, et al: Opisthorchiasis and opisthorchis-associated cholangiocarcinoma in Thailand and Laos. Acta Trop 120 (Suppl 1): S158-S168, 2011

3. Khan SA, Taylor-Robinson SD, Toledano MB, Beck A, Elliott P and Thomas HC: Changing international trends in mortality rates for liver, biliary and pancreatic tumours. J Hepatol 37: 806-813, 2002.

4. Bridgewater J, Galle PR, Khan SA, Llovet JM, Park JW, Patel T, Pawlik TM and Gores GJ: Guidelines for the diagnosis and management of intrahepatic cholangiocarcinoma. J Hepatol 60 $1268-1289,2014$

5. Marin JJ, Romero MR and Briz O: Molecular bases of liver cancer refractoriness to pharmacological treatment. Curr Med Chem 17: 709-740, 2010.

6. Dhanasekaran R, Hemming AW, Zendejas I, George T, Nelson DR, Soldevila-Pico C, Firpi RJ, Morelli G, Clark V and Cabrera R: Treatment outcomes and prognostic factors of intrahepatic cholangiocarcinoma. Oncol Rep 29: 1259-1267, 2013.

7. Srimunta U, Sawanyawisuth K, Kraiklang R, Pairojkul C Puapairoj A, Titipungul T, Hahnvajanawong C, Tassaneeyakul W, Wongkham C, Wongkham S and Vaeteewoottacharn K: High expression of $\mathrm{ABCCl}$ indicates poor prognosis in intrahepatic cholangiocarcinoma. Asian Pac J Cancer Prev 13 (Suppl): S125-S130, 2012.

8. Prakobwong S, Gupta SC, Kim JH, Sung B, Pinlaor P, Hiraku Y, Wongkham S, Sripa B, Pinlaor S and Aggarwal BB: Curcumin suppresses proliferation and induces apoptosis in human biliary cancer cells through modulation of multiple cell signaling pathways. Carcinogenesis 32: 1372-1380, 2011

9. Pawar P, Ma L, Byon CH, Liu H, Ahn EY, Jhala N, Arnoletti JP, McDonald JM and Chen Y: Molecular mechanisms of tamoxifen therapy for cholangiocarcinoma: Role of calmodulin. Clin Cancer Res 15: 1288-1296, 2009.

10. Taniai M, Grambihler A, Higuchi H, Werneburg N, Bronk SF, Farrugia DJ, Kaufmann SH and Gores GJ: Mcl-1 mediates tumor necrosis factor-related apoptosis-inducing ligand resistance in human cholangiocarcinoma cells. Cancer Res 64: 3517-3524, 2004

11. Yamagiwa Y, Marienfeld C, Meng F, Holcik M and Patel T: Translational regulation of X-linked inhibitor of apoptosis protein by interleukin-6: A novel mechanism of tumor cell survival. Cancer Res 64: 1293-1298, 2004.

12. Chang Q, Liu ZR, Wang DY, Kumar M, Chen YB and Qin RY: Survivin expression induced by doxorubicin in cholangiocarcinoma. World J Gastroenterol 10: 415-418, 2004.

13. Beishline $\mathrm{K}$ and Azizkhan-Clifford J: Spl and the 'hallmarks of cancer'. FEBS J 282: 224-258, 2015.

14. Wang L, Wei D, Huang S, Peng Z, Le X, Wu TT, Yao J, Ajani J and Xie K: Transcription factor Spl expression is a significant predictor of survival in human gastric cancer. Clin Cancer Res 9 : 6371-6380, 2003.

15. Jiang NY, Woda BA, Banner BF, Whalen GF, Dresser KA and Lu D: Sp1, a new biomarker that identifies a subset of aggressive pancreatic ductal adenocarcinoma. Cancer Epidemiol Biomarkers Prev 17: 1648-1652, 2008.

16. Vizcaino C, Mansilla S and Portugal J: Sp1 transcription factor: A long-standing target in cancer chemotherapy. Pharmacol Ther 152: 111-124, 2015.

17. Lee TJ, Jung EM, Lee JT, Kim S, Park JW, Choi KS and Kwon TK: Mithramycin A sensitizes cancer cells to TRAIL-mediated apoptosis by down-regulation of XIAP gene promoter through Sp1 sites. Mol Cancer Ther 5: 2737-2746, 2006.
18. Choi ES, Nam JS, Jung JY, Cho NP and Cho SD: Modulation of specificity protein 1 by mithramycin A as a novel therapeutic strategy for cervical cancer. Sci Rep 4: 7162, 2014.

19. Barcelo F, Ortiz-Lombardia M, Martorell M, Oliver M, Méndez C, Salas JA and Portugal J: DNA binding characteristics of mithramycin and chromomycin analogues obtained by combinatorial biosynthesis. Biochemistry 49: 10543-10552, 2010.

20. Chatterjee S, Zaman K, Ryu H, Conforto A and Ratan RR: Sequence-selective DNA binding drugs mithramycin A and chromomycin A3 are potent inhibitors of neuronal apoptosis induced by oxidative stress and DNA damage in cortical neurons. Ann Neurol 49: 345-354, 2001.

21. Gause GF: Olivomycin, mithramycin, chromomycin: Three related cancerostatic antibiotics. Adv Chemother 2: 179-195, 1965.

22. Schmitz H, Heinemann B, Lein J and Hooper IR: NSC A-649, an antitumor antibiotic. Antibiot Chemother (Northfield) 10: 740-746, 1960.

23. Reynolds RD, Fisher JI, Jensen PA, Pajak TF and Bateman JR: Phase I alternate-day dose study of chromomycin A3. Cancer Treat Rep 60: 1251-1255, 1976.

24. Samal B, Jones S, Brownlee RW, Morrison F, Hoogstraten B, Caoili E and Baker L: Chromomycin A3 for advanced breast cancer: A Southwest oncology group study. Cancer Treat Rep 62: 19-22, 1978.

25. Iranpour FG, Nasr-Esfahani MH, Valojerdi MR and al-Taraihi TM: Chromomycin A3 staining as a useful tool for evaluation of male fertility. J Assist Reprod Genet 17: 60-66, 2000.

26. Boer DR, Canals A and Coll M: DNA-binding drugs caught in action: The latest 3D pictures of drug-DNA complexes. Dalton Trans 399-414, 2009.

27. Miller SC, Huang R, Sakamuru S, Shukla SJ, Attene-Ramos MS, Shinn P, Van Leer D, Leister W, Austin CP and Xia M: Identification of known drugs that act as inhibitors of NF-kappaB signaling and their mechanism of action. Biochem Pharmacol 79: 1272-1280, 2010

28. Sripa B, Leungwattanawanit S, Nitta T, Wongkham C, Bhudhisawasdi V,Puapairoj A, Sripa C and Miwa M: Establishment and characterization of an opisthorchiasis-associated cholangiocarcinoma cell line (KKU-100). World J Gastroenterol 11: 3392-3397, 2005.

29. Saisomboon S, Kariya R, Vaeteewoottacharn K, Wongkham S, Sawanyawisuth K and Okada S: Antitumor effects of flavopiridol, a cyclin-dependent kinase inhibitor, on human cholangiocarcinoma in vitro and in an in vivo xenograft model. Heliyon 5 : $\mathrm{e} 01675,2019$

30. Schneider CA, Rasband WS and Eliceiri KW: NIH Image to ImageJ: 25 years of image analysis. Nat Methods 9: 671-675, 2012.

31. Phoomak C, Silsirivanit A, Park D, Sawanyawisuth K, Vaeteewoottacharn K, Wongkham C, Lam EW, Pairojkul C, Lebrilla CB and Wongkham S: O-GlcNAcylation mediates metastasis of cholangiocarcinoma through FOXO3 and MAN1A1. Oncogene 37: 5648-5665, 2018.

32. Cerella C, Muller F, Gaigneaux A, Radogna F, Viry E, Chateauvieux S, Dicato M and Diederich M: Early downregulation of Mcl-1 regulates apoptosis triggered by cardiac glycoside UNBS1450. Cell Death Dis 6: e1782, 2015.

33. Cai J, Wang D, Bai ZG, Yin J, Zhang J and Zhang ZT: The long noncoding RNA XIAP-AS1 promotes XIAP transcription by XIAP-AS1 interacting with Sp1 in gastric cancer cells. PLoS One 12: e0182433, 2017.

34. Obchoei S, Weakley SM, Wongkham S, Wongkham C, Sawanyawisuth K, Yao Q and Chen C: Cyclophilin A enhances cell proliferation and tumor growth of liver fluke-associated cholangiocarcinoma. Mol Cancer 10: 102, 2011.

35. Ono A, Hattori S, Kariya R, Iwanaga S, Taura M, Harada H, Suzu S and Okada S: Comparative study of human hematopoietic cell engraftment into BALB/c and C57BL/6 strain of rag-2/jak3 double-deficient mice. J Biomed Biotechnol 2011: 539748, 2011.

36. Harlow E and Lane D: Preparing paraffin tissue sections for immunostaining. CSH Protoc 2006: pdb.prot4329, 2006.

37. Vaeteewoottacharn K, Kariya R, Dana P, Fujikawa S, Matsuda K, Ohkuma K, Kudo E, Kraiklang R, Wongkham C, Wongkham S and Okada S: Inhibition of carbonic anhydrase potentiates bevacizumab treatment in cholangiocarcinoma. Tumour Biol 37: 9023-9035, 2016.

38. Parrish AB, Freel CD and Kornbluth S: Cellular mechanisms controlling caspase activation and function. Cold Spring Harb Perspect Biol 5: a008672, 2013. 
39. Bedolla RG, Gong J, Prihoda TJ, Yeh IT, Thompson IM, Ghosh R and Kumar AP: Predictive value of Sp1/Sp3/FLIP signature for prostate cancer recurrence. PLoS One 7: e44917, 2012.

40. Lau R, Niu MY and Pratt MA: cIAP2 represses IKK $\alpha / \beta$-mediated activation of MDM2 to prevent p53 degradation. Cell Cycle 11: 4009-4019, 2012.

41. Patel T: Cholangiocarcinoma-controversies and challenges. Nat Rev Gastroenterol Hepatol 8: 189-200, 2011

42. Kobayashi S, Werneburg NW, Bronk SF, Kaufmann SH and Gores GJ: Interleukin-6 contributes to Mcl-1 up-regulation and TRAIL resistance via an Akt-signaling pathway in cholangiocarcinoma cells. Gastroenterology 128: 2054-2065, 2005.
43. Sleire L, Forde HE, Netland IA, Leiss L, Skeie BS and Enger PO: Drug repurposing in cancer. Pharmacol Res 124: 74-91, 2017.

44. Guimaraes LA, Jimenez PC, Sousa Tda S, Freitas HP, Rocha DD, Wilke DV, Martín J, Reyes F, Deusdênia Loiola Pessoa O and Costa-Lotufo LV: Chromomycin A2 induces autophagy in melanoma cells. Mar Drugs 12: 5839-5855, 2014.

(i) This work is licensed under a Creative Commons Attribution-NonCommercial-NoDerivatives 4.0 International (CC BY-NC-ND 4.0) License. 